\title{
ANTIBACTERIAL ACTIVITY OF LENTINULA EDODES GROWN IN LIQUID MEDIUM
}

\author{
Noemia Kazue Ishikawa; Maria Catarina Megumi Kasuya; Maria Cristina Dantas Vanetti* \\ Departamento de Microbiologia, Universidade Federal de Viçosa, Viçosa, MG, Brasil
}

Submitted: July 26, 2000; Returned to authors for corrections: January 21, 2001; Approved: June 26, 2001

\begin{abstract}
The antibacterial activity of 35 isolates of Lentinula edodes, a shiitake mushroom, against Bacillus subtilis was evaluated by diffusion technique in agar with a semi-solid overlay. All isolates inhibited B. subtilis and the isolate Le1 promoted the formation of the largest inhibition zone. L. edodes Le1 also presented antibacterial activity against foodborne pathogens and food contaminant bacteria, particularly Grampositive species. The antibacterial activity of the culture filtrate after 18-25 days of cultivation of $L$. edodes in broth at $25^{\circ} \mathrm{C}$ was high. The inhibitory activity was observed only in the organic layer when the culture filtrate was partitioned between ethyl acetate and water, suggesting that the inhibitory substances have low polarity. The silica gel thin-layer zone at $R f$ values of $0.63-0.80$, developed in chloroform - acetone ethyl acetate - methanol $=40: 5: 5: 2$, was responsible for the antibacterial activity against $B$. subtilis. The inhibitory activity of $L$. edodes was detectable in the culture filtrate after heat treatment at $100^{\circ} \mathrm{C}$ for $10 \mathrm{~min}$ and after storage at $4^{\circ} \mathrm{C}$ for 120 days.
\end{abstract}

Key words: antibacterial activity, Lentinula edodes, shiitake

\section{INTRODUCTION}

The shiitake mushroom, Lentinula edodes (Berkeley) Pegler, is the most commercially important mushroom grown on wood (23). It is considered a delicacy and an essential ingredient for many Japanese and Chinese dishes (24). The cultivation of shiitake is expanding in Brazil, using eucalypt logs, particularly in the South and Southeastern regions, due to favorable climatic conditions. Shiitake is a model among functional mushrooms for extensive research of its bioactivity leading to the isolation of pure compounds which have pharmaceutical status (3). Medicinal properties such as anti-tumor $(5,15)$, anticarcinogenic (19), anti-viral $(12,17,21)$, preventive blood pressure increase in hypertension cases $(9)$, and hypocholesterolemic $(4,20)$ have been attributed to active substances extracted from $L$. edodes. Antibacterial, antifungal and antiviral activities were also reported (8). The antimicrobial activity of $L$. edodes against Trichoderma, the main genus detected in damaged bedlog, was related by Tokimoto et al. (22), who verified the increasing production of antifungal substances by shiitake in the presence of this contaminant. The inhibitory activity in L. edodes culture broth against bacteria and fungi has also been observed $(13,14)$.

In this study we verified the inhibitory activity of $L$. edodes isolates against $B$. subtilis and on some foodborne bacteria.

\section{MATERIALS AND METHODS}

\section{Organisms}

Sixteen of thirty five strains of $L$. edodes used in this study were isolated from mushrooms of shiitake growers in Paraná, São Paulo and Minas Gerais states in Brazil. The remaining cultures were kindly provided by the collection of Botanic Institute of São Paulo, Brazil. The stock cultures were kept in tubes with potato dextrose agar (PDA, Merck). Mycelium of each stock was cultured at $25^{\circ} \mathrm{C}$ on the surface of malt extract agar (Difco) in $9 \mathrm{~cm}$ diameter Petri dishes. After 15 days, mycelial disks were punched out with a $7 \mathrm{~mm}$ diameter cork borer. Foodborne pathogenic and spoilage bacteria strains, listed in Table 1, were from the culture

\footnotetext{
* Corresponding author. Mailing address: Departamento de Microbiologia, Universidade Federal de Viçosa, 36571-000, Viçosa, MG, Brasil. Tel.(+5531) 899-2954. Fax: (+5531) 899-2573. E-mail: mvanetti@mail.ufv.br
} 
collection of the Food Microbiology Laboratory at the University Federal of Viçosa (MG), Brazil. Stocks were maintained on Brain Heart Infusion (BHI, Merck) slants at $4^{\circ} \mathrm{C}$.

\section{Antibacterial activity of $L$. edodes}

The evaluation of inhibitory activity of 35 cultures of $L$. edodes was performed according to the modified method of Spelhaug and Harlander (18). The mycelial disks ( $7 \mathrm{~mm}$ diameter) of fungal strains were transferred onto malt extract agar. After 3 days incubation at $25^{\circ} \mathrm{C}, 7 \mathrm{ml}$ of semi-solid $\mathrm{BHI}$ inoculated with about $10^{5} \mathrm{CFU} / \mathrm{ml}$ of $B$. subtilis was carefully poured on the plate surface as an overlay. B. subtilis was chosen as indicator bacterium because, in preliminary tests, its growth was markedly inhibited by the presence of $L$. edodes. Furthermore, this bacterium was also used by Komemushi et al. (13) to test the antimicrobial activity of $L$. edodes.

The Petri dishes were allowed to stand for 8 hours at $4^{\circ} \mathrm{C}(6)$ for diffusion of the metabolites of $L$. edodes culture to the BHI overlay and then incubated at $37^{\circ} \mathrm{C}$ for $18 \mathrm{hs}$. Antibacterial activity was determined by measuring the radius of the clear inhibition zone around each mycelial disk. Four replicates were made for each $L$. edodes culture. The strain of $L$. edodes that showed the highest antagonistic activity against $B$. subtilis was selected for evaluation of the antibacterial activity against the foodborne bacteria listed in Table 1.

The antibacterial activity of $L$. edodes was either evaluated on liquid culture filtrate or on mycelium biomass. The fungi were cultured in $250 \mathrm{ml}$ Erlenmeyer flasks containing $50 \mathrm{ml}$ of malt extract broth. After 30 days incubation at $25^{\circ} \mathrm{C}$, as static cultures, the mycelial biomass was retained on a sieve, and the broth was sterilized by filtration through a $0.45 \mu \mathrm{m}$ pore-size membrane. The mycelium extract was prepared according to Kasuya (10). The antibacterial activity was determined on $3 \mathrm{ml}$ BHI broth dispensed in screw cap tubes inoculated with about $10^{5} \mathrm{CFU} / \mathrm{ml}$ of a $18 \mathrm{hs}$ culture of $B$. subtilis. One milliliter of $L$. edodes culture filtrate or extract of mycelial was added, and the bacterial growth was determined by measuring the optical density (OD) at $600 \mathrm{~nm}$ and by the number of viable cells on BHI agar inoculated with a spiral plater (Spiral Biotech, Inc. mod. 4000 , Bethesda, MD). In the control tube, $1 \mathrm{ml}$ of sterilized water was added instead of the filtrate or extract. Percentage of inhibition was calculated using the formula: [(OD control - OD filtrate or extract)/OD control] x 100. The experiment was done in triplicates.

The effect of incubation time upon the antibacterial activity of $L$. edodes was tested using the filtrate obtained from cultures incubated in malt extract broth, at $25^{\circ} \mathrm{C}$ over 40 days. Periodically, three flasks were removed to evaluate spectrophotometrically the $B$. subtilis inhibition in BHI broth.

Extraction of antibacterial substance of filtrate broth was performed according to the procedure of Kasuya et al. (11). Briefly, L. edodes was grown in $50 \mathrm{ml}$ malt extract broth for 30 days at $25^{\circ} \mathrm{C}$. The constituents in the culture filtrate were partitioned between ethyl acetate and water. The inhibitory activity of organic and aqueous fractions was evaluated using paper disks imbibed with sample solutions. B. subtilis was used as the indicator bacterium and was spread over plate surface before the filter-papers were placed. The plates were maintained in a refrigerator for $8 \mathrm{~h}$ for diffusion of substances from paper disk to agar and then, incubated at $37^{\circ} \mathrm{C}$ for $18 \mathrm{hs}$. The radius of the inhibitory zone was recorded. Control tests with solvent gave no zones of inhibition.

Table 1. Radius of the inhibition halo of foodborne pathogens and food contaminant bacteria caused by the culture filtrate of Lentinula edodes Le1.

\begin{tabular}{|c|c|c|c|}
\hline \multicolumn{2}{|l|}{ Bacteria } & Strain & $\begin{array}{l}\text { Inhibition } \\
\text { halo (mm) }\end{array}$ \\
\hline \multicolumn{4}{|l|}{ Gram-positive } \\
\hline \multirow[t]{2}{*}{ Bacillus cereus } & & F 4433 & 12 \\
\hline & & F 4810 & 11 \\
\hline B. subtilis & & LMA 0011 & 28 \\
\hline \multirow[t]{2}{*}{ Listeria innocua } & & 12570 & 8 \\
\hline & & L6A & 4 \\
\hline \multirow[t]{5}{*}{ L. monocytogenes } & & ATCC 7644 & 4 \\
\hline & & Scott A & 3 \\
\hline & $(1)$ & & 0 \\
\hline & (1) & & 0 \\
\hline & (1) & & 13 \\
\hline \multirow[t]{3}{*}{ Staphylococcus aureus } & (2) & & 13 \\
\hline & (3) & & 15 \\
\hline & (4) & & 19 \\
\hline S. epidermidis & & ATCC 12228 & 27 \\
\hline \multicolumn{4}{|l|}{ Gram-negative } \\
\hline Acinetobacter & $(2)$ & & 0 \\
\hline Citrobacter amaloni & (3) & & 0 \\
\hline Enterobacter cloacae & & ATCC 23355 & 0 \\
\hline \multirow[t]{2}{*}{ Escherichia coli } & & ATCC 25922 & 0 \\
\hline & $(4)$ & & 0 \\
\hline Enteropathogenic E. coli & & & 0 \\
\hline Klebsiella pneumoniae & & ATCC 13883 & 4 \\
\hline Proteus mirabilis & & ATCC 25933 & 4 \\
\hline Pseudomonas aeruginosa & $(2)$ & & 0 \\
\hline P. maltophila & (2) & & 6 \\
\hline Salmonella anatum & & 9021 & 0 \\
\hline S. galinarium & & LMA 0021 & 0 \\
\hline S. saintpaul & & LMA 0022 & 0 \\
\hline Salmonella sp. & (3) & & 0 \\
\hline Serratia marcescens & (3) & & 0 \\
\hline Shigella sonnei & (4) & & 0 \\
\hline Yersinia enterocolitica & (4) & & 5 \\
\hline
\end{tabular}

(1) Isolated from foods; (2) Isolated from food handler; (3) Isolated from food implement surface; (4) Isolated from food utensils. 
The heat stability of antibacterial substances from L. edodes was evaluated by using samples heated at $100^{\circ} \mathrm{C}$ for $10,20,30$ and $60 \mathrm{~min}$. After heat treatment, the filtrate was quickly cooled in an ice bath. The control filtrate was left at room temperature. The inhibitory activity against $B$. subtilis was determined on spectrophotometer, as described before.

\section{TLC-bioautography}

Pre-coated glass plates of Silica Gel $60 \mathrm{~F}_{254}$ (Merck) were used to detect the ethyl acetate soluble antibacterial compounds in the culture filtrate. An aliquot of ethyl acetate extract equivalent to $581.24 \mathrm{mg}$ of mycelial dry matter was charged on the plate and developed in a solvent system of chloroform acetone - ethyl acetate - methanol = 40:5:5:2. After development, the solvents were evaporated under reduced pressure and the bands of quenching and fluorescent compounds were observed under UV light at 254 and 366nm, respectively. For bioautography, $40 \mathrm{ml}$ of semi solid BHI inoculated with $B$. subtilis was sprayed to TLC plates. After $1 \mathrm{~h}$ at refrigerator temperature, the plates were incubated for $15 \mathrm{hs}$ at $37^{\circ} \mathrm{C}$ in a box lined with wet filter paper to maintain high humidity. Application of a superficial layer of aesculin lead to better observation of inhibition zone (25). The plates were incubated for an additional 4hs to allow hydrolysis of aesculin by $B$. subtilis.

\section{RESULTS AND DISCUSSION}

All isolates of L. edodes inhibited the growth of B. subtilis, determined by the formation of an inhibition halo (Fig. 1).
However, this antimicrobial activity varied markedly. The isolate Le1 promoted the formation of the largest inhibition halo and was selected for further study.

The isolated Le1 presented antibacterial activity against 8 species out of 20 foodborne pathogens and food contaminants, mainly on Gram-positive bacteria (Table 1). Coletto (2) observed the antimicrobial activity of $L$. edodes upon Gram-positive bacteria as Staphylococcus aureus and B. subtilis, but not upon Escherichia coli. However, Herrmann (7) and Komemushi et al. (13) showed inhibitory effect upon Gram-positive and negative bacteria. In our study, B. cereus, B. subtilis, S. aureus, and $S$. epidermidis presented high sensitivity to metabolic compounds of $L$. edodes. B. cereus and $S$. aureus are widely recognized as important foodborne pathogens and the potential of its inhibition presented by $L$. edodes may receive more attention. Although the in vivo effect of antibacterial substance of $L$. edodes was shown to be due to the induction complement $\mathrm{C} 3$ elevation that increased the resistance to infection (16), the results presented here suggest that some direct antibacterial effect would occur and should be further exploited.

The inhibition of B. subtilis growth observed in the broth containing mycelium culture filtrate, and the lag phase detected in the broth with mycelium extract (Fig. 2) indicate that the substance(s) of L. edodes with potential inhibitory effect is(are) both extra and intracellular. Similar results were also observed by Komemuschi et al. (13).

The inhibition of $B$. subtilis growth was observed when mycelial filtrate was added to BHI broth (Fig. 2). The number of viable cells of $B$. subtilis after $12 \mathrm{hs}$ at $37^{\circ} \mathrm{C}$ remained quite

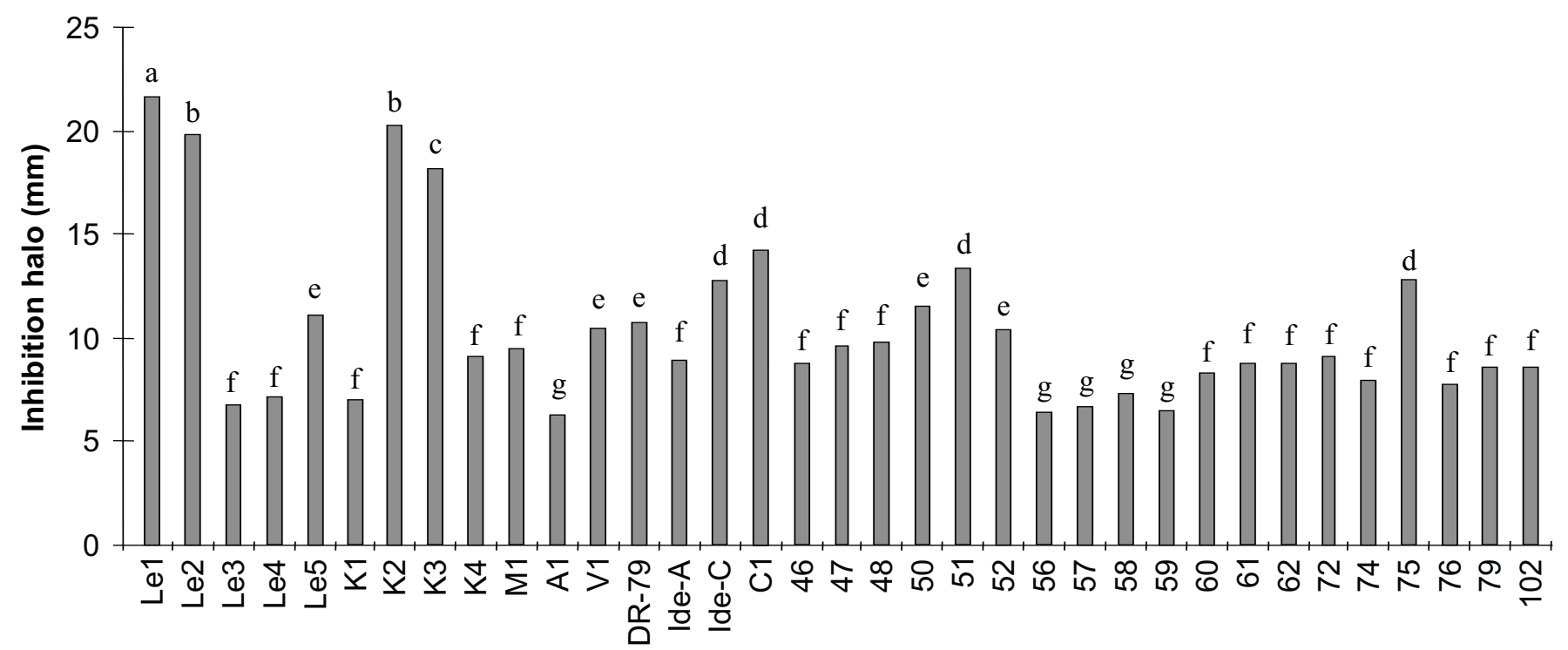

\section{Lentinula edodes isolates}

Figure 1. Inhibition halo (mm) of Bacillus subtilis by Lentinula edodes isolates. Bars followed by the same letter do not differ by Scott Knott test $(\mathrm{P} \leq 0.05)$. 


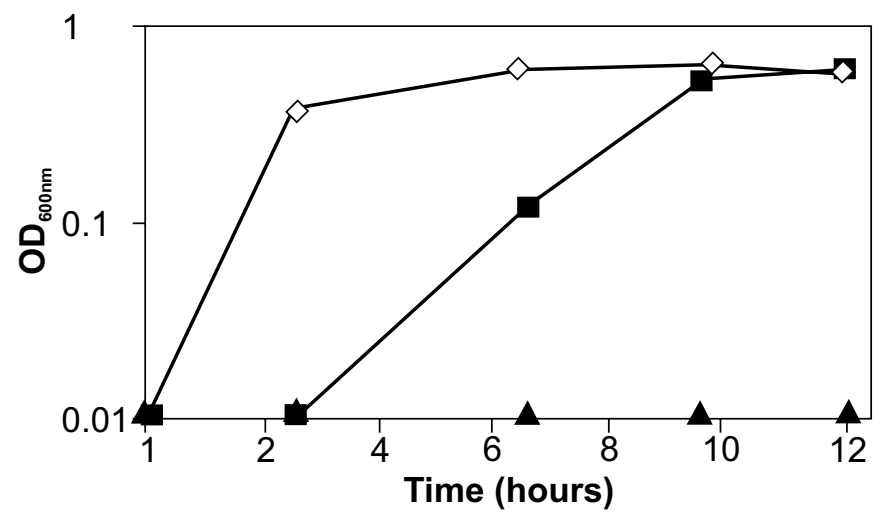

Figure 2. Growth of Bacillus subtilis, at $37^{\circ} \mathrm{C}$ in $\mathrm{BHI}$, alone $(-\diamond-)$ or added with mycelium culture filtrate $\left(-\mathbf{A}_{-}\right)$or mycelium extract (-口-) of Lentinula edodes.

constant, $10^{3} \mathrm{CFU} / \mathrm{ml}$, compared to the variation of $5 \log$ cycles observed in the control, during the same time of incubation. This suggested that the effect of inhibitory substance was bacteriostatic.

The antibacterial activity of the mycelium filtrate was dependent on the age of $L$. edodes culture. The highest inhibition was observed between 18 to 25 days of cultivation in malt extract broth at $25^{\circ} \mathrm{C}$, when the growth inhibition was, respectively, 84 and $100 \%$ after $12 \mathrm{hs}$ incubation (data not shown).

The inhibitory activity was observed in the organic layer, after extraction of the culture filtrate with ethyl acetate, indicating that inhibitory activity is due to substances with low polarity. The results observed with the water and ethyl acetate soluble fractions showed the inhibitory activity only around the paper disks treated with the ethyl acetate extract. Antifungal substances produced by $L$. edodes have been identified as straight-chain alcohol with 8-9 carbons, having double and triple bonds (22). One of these substances was lentinamycin, extracted and identified by Bew et al. (1). Lentinamycin was the main cause of the antimicrobial activity of the culture filtrate of $L$. edodes upon bacteria, filamentous fungi and yeasts (14).

The heating of L. edodes filtrate at $100^{\circ} \mathrm{C}$ for $10 \mathrm{~min}$ did not cause a significant loss of antibacterial activity against $B$. subtilis (Fig. 3). However, the increase of the exposition time to 20, 30 and $60 \mathrm{~min}$ resulted in 43,72 and $100 \%$, of activity reduction, respectively, when compared with that of filtrate maintained at room temperature.

In the bioautography on TLC, an inhibition activity against $B$. subtilis was observed between $R f 0.63$ and 0.80 . The large range of $R f$ observed may be due to the diffusion and/or volatile property of the active principles. The presence of inhibitory substance in the culture broth of L. edodes against Aspergillus ochraceus, after fractionating on TLC with benzene - ethyl acetate $=75: 25$, was also observed by Komemushi et al. (13), and the inhibitory zone was around $R f 0.60$.

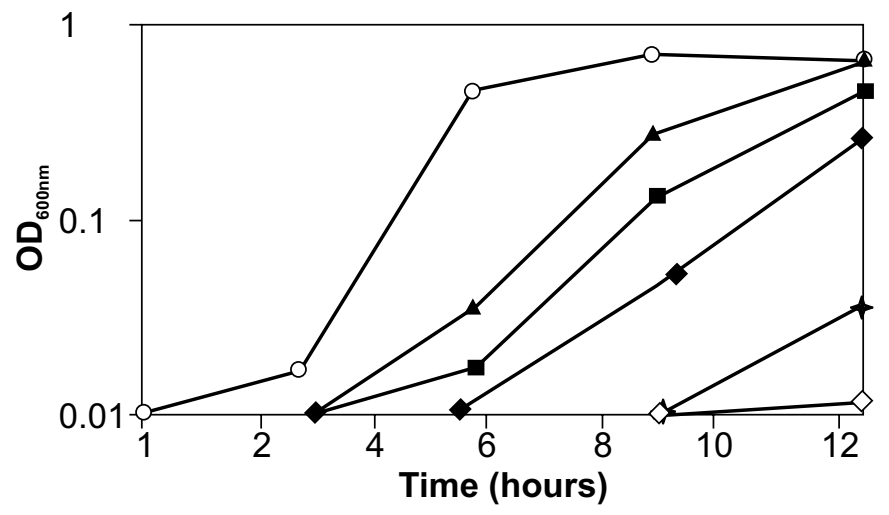

Figure 3. Effect of heat treatment of culture filtrate of the Lentinula edodes on the growth of Bacillus subtilis: control (BHI broth without filtrate) $(\mathrm{O})$; filtrate without heat treatment $(\diamond)$; filtrate heated at $100^{\circ} \mathrm{C} / 10 \mathrm{~min} .(\diamond) ; 100^{\circ} \mathrm{C} / 20 \mathrm{~min} .(\diamond)$; $100^{\circ} \mathrm{C} / 30 \mathrm{~min}$. (ם); $100^{\circ} \mathrm{C} / 60 \mathrm{~min}$. (A).

Considering the potential use of natural antimicrobial compounds in food processing, at present we are working on the isolation and identification of the major antimicrobial agents produced by L. edodes.

\section{ACKNOWLEDGEMENTS}

To FAPEMIG (Fundação de Amparo à Pesquisa do Estado de Minas Gerais) by the financial support (CBS-1369/97; to Dr. S. Tahara and Dr. Miura, from Faculty of Agriculture of Hokkaido University, for reading the manuscript and giving useful suggestions; and to Dr. Chun Keun Lim, Lab. of Bacteriology Division of Environmental Biology - Kangwon National University - Korea, for confirming Bacillus subtilis identification.

\section{RESUMO}

\section{Atividade antibacteriana de Lentinula edodes cultivado em meio líquido}

A atividade antibacteriana de 35 isolados de Lentinula edodes (shiitake) contra Bacillus subtilis foi avaliada pela técnica de difusão em sobrecamada de ágar semi-sólido. Todos os isolados avaliados inibiram o crescimento de B. subtilis sendo o isolado Le1 o que apresentou maior halo de inibição. L. edodes Le1 também inibiu o crescimento de bactérias patogênicas e deterioradoras de alimentos, especialmente as Gram-positivas. Maior atividade antibacteriana do filtrado da cultura de L. edodes em meio líquido foi observada entre 18-25 dias de incubação, a $25^{\circ} \mathrm{C}$. O fracionamento do filtrado da cultura com acetato de etila e água permitiu evidenciar a atividade antagonista somente na fase orgânica, sugerindo que as substâncias inibitórias apresentam baixa poloridade. A cromatografia em camada fina, 
com o sistema de solventes clorofórmio - acetona - acetato de etila - metanol $=40: 5: 5: 2$, definiu a região de Rf entre 0,63-0,80 como a que apresenta atividade antibacteriana contra $B$. subtilis. A atividade inibitória de $L$. edodes foi detectada em filtrado da cultura após o tratamento térmico de $100^{\circ} \mathrm{C}$ por 10 minutos e após estocagem a $4^{\circ} \mathrm{C}$ por 120 dias.

Palavras-chave: atividade antibacteriana, Lentinula edodes, shiitake

\section{REFERENCES}

1. Bew, R.E.; Chapman, J.R.; Jones, Sir Ewart R.H.; Lowe, B.E.; Lowe, G. Natural acetylenes. Part XVIII. Some Allenic Polyacetylenes from basidiomycetes. J. Chem. Soc., 1966:129-135, 1966.

2. Coletto, B. Basidiomiceli in relazione all'antibiosi nota II. Attivita'antibiotica dei miceli e dei liquidi di coltura. Giorn. Batt. Virol. Immun., 74:267-274, 1981.

3. Chang, R. Funcional properties of edible mushrooms. Nutr. Rev., 54:S91-S93, 1996.

4. Chibata, I.; Okumura, K.; Takeyama, S.; Kotera, K. Lentinacin: a new hypocholesterolemic substance in Lentinus edodes. Specialia, 25:237-1238, 1969.

5. Chihara, G.; Maeda, Y.; Hamuro, J.; Sasaki, T.; Fukuoka, F. Inhibition of mouse sarcoma 180 by polysaccharides from Lentinula edodes (Berk:) Sing. Nature, 222:687-688, 1969.

6. Fermor, T.R.; Wood, D.A. Degradation of bacteria by Agaricus bisporus and other fungi. J. Gen. Microbiol., 126:377-387, 1981.

7. Herrmann, H. Cortinellin, eine antibiotisch wirksame substanz aus Cortinellus shiitake. Die Natur. Wissenschaften, 49:542, 1962.

8. Jong, S.C.; Birmingham, J. Medicinal and therapeutic value of the shiitake mushroom. In: Neidleman, S.; Laskin, A.I. Adv. Appl. Microbiol., 39:153-183, 1993.

9. Kabir, Y.; Kamaguchi, M.; Kimura, S. Effect of shiitake (Lentinus edodes) and maitake (Grifora frondosa) mushrooms on blood pressure and plasma lipids of spontaneously hypertensive rats. J. Nutr. Sci. Vitaminol., 33:341-346, 1987.

10. Kasuya, M.C.M. Ecological and physiological studies on ectomycorrhizae of Picea glehnii (Fr. Schm.) masters. DS thesis, Hokkaido University, Sapporo, Hokkaido, 1995.

11. Kasuya, M.C.M.; Tahara, S.; Igarashi, T. Growth inhibition of pathogenic root fungi by extracts of ectomycorrhizal fingi or
Picea glehnii inoculated with ectomycorrhizal fungi. Biotropia 9:53-61, 1996.

12. Kobayashi, N.; Hiramatsu, A.; Akatsuka, T. Purification and chemical properties of an inhibitor of plant virus infection from fruting bodies of Lentinus edodes. Agric. Biol. Chem., 51:883-890, 1987.

13. Komemushi, S.; Yamamoto, Y.; Fujita, T. Antimicrobial substance by Lentinus edodes. J. Antibact. Antifung. Agents, 23:81-86, 1995.

14. Komemushi, S.; Yamamoto, Y.; Fujita, T. Purification and identification of antimicrobial substances produced by Lentinus edodes. J. Antibact. Antifung. Agents, 24:21-25, 1996.

15. Maeda, Y.Y.; Takahama, S.; Yonekawa, H. Four dominant loci for the vascular responses by the antitumor polysaccharide, lentinan. Immunogenetics, 47:159-165, 1998.

16. Sakamoto, M.; Ishii, S.; Nishioka, K. Heightened resistance against Listeria monocytogenes infection in malnourished rats after lentinan treatment: correlation with C3 levels. Nutr. Res., 3:705-718, 1983.

17. Sarkar, S.; Koga, J.; Whitley, R.J.; Chatterjee, S. Antiviral effect of the extract of culture medium of Lentinus edodes mycelia on the replication of herpes simplex virus type 1. Antiviral Res., 20:293303, 1993.

18. Spelhaug, S.R.; Harlander, S.K. Inhibition of foodborne bacterial pathogens by bacteriocins from Lactococcus lactis and Pediococcus pentosaceous. J. Food Protect., 52:856-862, 1989.

19. Sugano, N.; Choji, Y.; Hibino, Y.; Yasumura, S.; Maeda, H. Anticarcinogenic action of an alcohol-insoluble fraction (LAP1) from culture medium of Lentinus edodes mycelia. Cancer Lett., 27:1-6, 1985.

20. Sugiyama, K.; Akachi, T.; Yamakawa, A. Eritadenina-induced alteration of hepatic phospholipid metabolism in relation to its hypocholesterolemic action in rats. J. Nutr. Biochem., 6:80-87, 1995.

21. Suzuki, H.; Iiyama, K.; Yoshida, O.; Yamazaki, S.; Yamamoto, N.; Toda, S. Structural characterization of the immunoactive and antiviral water-solubilized lignin in an extract of the culture medium of Lentinus edodes mycelia (LEM). Agric. Biol. Chem., 54:479. 487, 1990.

22. Tokimoto, K.; Fujita, T.; Takeda, Y.; Takaishi, Y. Increased or induced formation of antifungal substances in cultures of Lentinus edodes by attack of Trichoderma spp. Proc. Japan Acad. Series B. Phys. and Biol. Sciences, 63:277-280, 1987.

23. Tokimoto, K.; Fukuda, M.; Tsuboi, M. Effect of the physical properties of Lentinula edodes bedlogs on fruiting body production. Mycoscience, 39:217-219, 1998.

24. Tsuneda, A. Shiitake and other edible mushrooms cultivated in Japan: production, biology, and breeding. In: Charalambous, G.: Spices, herbs and edible fungi. 1994, pp.685-727.

25. Weinstein, L.I.; Hahn, M.G.; Albersheim, P. Host-pathogen interactions. Plant Physiol., 68:358-363, 1981. 